\title{
Produksi Video Konten Religi Kamus Ustadz Untuk Aplikasi ROOV Di PT MNC Networks
}

\section{The Production of Kamus Ustadz Religion Content Video for ROOV Application at PT MNC Networks}

\author{
Alvian Adie Pradana ${ }^{1}$, Bayu Widodo ${ }^{1}$, Aditya Eka Purwanto ${ }^{2}$ \\ ${ }^{1}$ Sekolah Vokasi Institut Pertanian Bogor, Jalan Kumbang 14, Bogor \\ ${ }^{2}$ PT MNC Networks, Jalan Kebon Sirih No 17-19, Menteng, Jakarta Pusat
}

Email : alvian.adie13@gmail.com,bayuwi@apps.ipb.ac.id, adityaeka21@gmail.com

\begin{abstract}
PT MNC Netrworks (MNC Radio Networks) developed an application called ROOV (Radio On The Move), an Android platform application that acts as an aggregator (collector) of almost all radio frequencies in Indonesia. ROOV users can listen to the radio on ROOV by streaming audio online.

Kamus Ustadz is one of the entertainment and educational video content types of Islamic religious videos that are on ROOV. Kamus Ustadz is content that can attract public interest because it is entertaining and meaningful content. Kamus Ustadz presents Islamic religious content, which is delivered lightly through humorousinterludes.

In producing religious video content, Kamus Ustadz uses theoretical methods starting from Pre-Production, Production, then Post-Production combined with practical methods in the field. The results of the production of religious video content of the Ustadz Dictionary will be published on ROOV to be presented to ROOV users so that ROOV users can be entertained and educated.

Keywords : Kamus Ustadz, radio, religious video, ROOV
\end{abstract}

\section{ABSTRAK}

PT MNC Networks (MNC Radio Networks) mengembangkan aplikasi bernama ROOV (Radio On The Move) yaitu aplikasi ber-platform Android yang bertindak sebagai aggregator (penghimpun) hampir seluruh frekuensi radio di Indonesia. Pengguna ROOV dapat mendengarkan radio di ROOV dengan cara streaming audio secara online.

Kamus Ustadz merupakan salah satu konten video hiburan dan edukatif berjenis video religi Islam yang ada di ROOV. Kamus Ustadz merupakan konten yang dapat menarik minat khalayak umun karena merupakan konten yang menghibur dan bermanfaat. Kamus Ustadz menyajikan konten religi Islam yang penyampaian materinya disampaikan secara ringan melalui selingan humor.

Dalam memproduksi konten video religi Kamus Ustadz digunakan metode teoritis yang dimulai dari Praproduksi, Produksi, kemudian Pascaproduksi yang dikombinasikan dengan metode praktis di lapangan. Hasil dari produksi konten video religi Kamus Ustadz akan dipublikasikan di ROOV untuk disajikan kepada pengguna ROOV sehingga pengguna ROOV dapat terhibur dan teredukasi.

Kata kunci : Kamus Ustadz, radio, ROOV, video religi 


\section{PENDAHULUAN}

Radio merupakan media komunikasi massa yang dapat dikonsumsi publik, pesannya bersifat umum dan berkesinambungan, serta aktualitas (berisi hal-hal baru, seperti laporan peristiwa terbaru) (Romli 2017:13).

Berdasarkan Survey Nielsen Consumer Media View pada tahun 2017 menyatakan bahwa pada 11 kota di Indonesia penetrasi radio mendapati kedudukan ke-4 dengan persentase sebagai berikut: Televisi (96\%), Media Luar Ruang (53\%), Internet (44\%), Radio (37\%), Koran (7\%), Tabloid, dan Majalah (3\%) (Nielsen 2017). Hal ini menunjukkan bahwa radio masih menjadi media komunikasi populer yang digunakan masyakarat umum namun popularitasnya berada di bawah internet. Internet lebih unggul dibandingkan dengan radio karena cakupan jarak akses internet jauh lebih luas (hingga ke seluruh dunia), lain halnya dengan radio yang cakupan jarak aksesnya relatif lebih kecil (terbatas pada luasnya cakupan transmisi gelombang radio). Dengan keunggulan yang dimiliki internet maka dikembangkan teknologi bernama radio internet. Radio internet bekerja dengan cara mentransmisikan gelombang suara lewat internet. (Priatna 2018:254).

PT MNC Networks (MNC Radio Networks) merupakan grup dari empat radio besar di Indonesia yakni Trijaya FM, Global Radio, V Radio, dan RDI. MNC Radio Networks bergerak pada bisnis penyiaran radio. MNC Radio Networks mengambil tindakan untuk mengatasi keterbatasan cakupan jarak akses radio dengan mengimplementasikan teknologi radio internet. Realisasinya adalah dengan mengembangkan aplikasi bernama ROOV (Radio On The Move). ROOV merupakan aplikasi yang bertindak sebagai aggregator (penghimpun) hampir seluruh frekuensi radio di Indonesia. ROOV menyajikan fitur untuk untuk mendengarkan radio dengan cara streaming audio melalui jaringan internet. Streaming adalah proses penghantaran data dalam aliran berkelanjutan dan tetap yang memungkinkan pengguna mengakses dan menggunakan file sebelum dihantar sepenuhnya (Munir 2012:365). Dengan cara tersebut maka pengguna ROOV dapat mendengarkan radio tanpa keterbatasan jarak. Saat ini ROOV tersedia untuk gawai bersistem operasi Android. Selain sebagai tempat untuk mendengarkan radio, ROOV juga memiliki fitur-fitur lain seperti konten-konten yang bersifat menghibur dan bermanfaat berupa :

- Berita kategori entertainment

- Podcast dari berbagai radio

- Konten video religi Islam Kamus Ustadz

- Konten video komedi Belajar Kumedi, Sofa So Good, dan Aloha Summer

Talk

- Konten video asmara Dokter Cinta

- $\quad$ Video dan podcast religi (Buddha, Hindu, Konghucu, Kristen, dan Islam)

Fitur-fitur tambahan tersebut bertujuan untuk menarik minat khalayak umum supaya tetap menggunakan radio sebagai media informasi maupun hiburan melalui ROOV. Berdasarkan tujuan tersebut, maka untuk menarik minat khalayak umum diperlukan konten yang menarik namun bermanfaat. Salah satunya adalah Kamus Ustadz yang merupakan konten video religi Islam yang 
penyampaian materinya disampaikan secara ringan melalui selingan humor. Kamus Ustadz adalah konten yang menghibur dan bermanfaat. Menghibur karena jalan ceritanya selalu disisipi unsur humor, bermanfaat sebab kontennya membahas mengenai masalah kehidupan sehari-hari dan masalah sosial yang ada di masyarakat kemudian memberikan solusi yang berorientasikan pada ajaran Islam.

Berdasarkan uraian tersebut, "Produksi Video Konten Religi Kamus Ustadz untuk Aplikasi ROOV di PT MNC Networks" dijadikan sebagai judul yang dipilih. Oleh karena itu, diharapkan dengan adanya konten ini dapat menghibur sekaligus mengedukasi pengguna ROOV.

\section{METODE PENELITIAN}

Metode yang digunakan dalam Produksi Video Konten Religi Kamus Ustadz merupakan metode teoritis yang dikombinasikan dengan metode praktis selama di lapangan untuk setiap produksi konten video.

Metode teoritis yang digunakan terdiri dari 3 tahapan yakni Praproduksi, Produksi, dan Pascaproduksi seperti yang ditunjukkan pada Gambar 1.

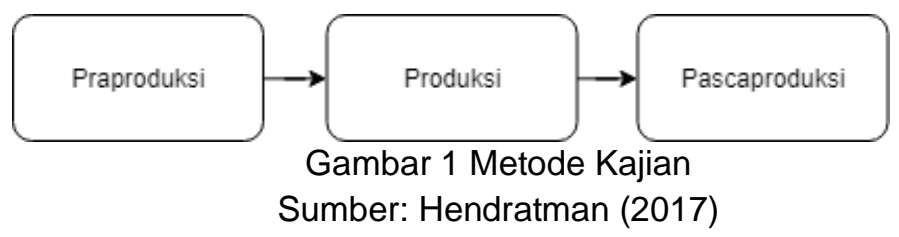

\section{Praproduksi}

Tahap praproduksi adalah tahap sebelum video diproduksi secara nyata (Hendratman 2017:716). Rangkaian proses pada tahap praproduksi adalah sebagai berikut :

\section{- Pencarian Referensi Topik}

Menurut Kamus Besar Bahasa Indonesia $(\mathrm{KBBI})$, referensi adalah sumber acuan, rujukan, atau petunjuk. Menurut KBBI, topik adalah pokok pembicaraan dalam diskusi. Pada proses pencarian referensi topik, topik merupakan bahan diskusi yang menjadi dasar terbentuknya ide-ide yang nanti akan disusun pada bagian penulisan naskah / script (scriptwriting).

\section{- Penentuan Target Audience}

Target audience adalah persoalan bagaimana memilih, menyeleksi, menjangkau audien sasaran (Morrisan 2008:174). Target audience ditentukan berdasarkan tiga segmen, yakni segmentasi demografis, segmentasi geografis, dan segmentasi psikografis. Segmentasi demografis pada dasarnya adalah segmentasi yang didasarkan pada peta kependudukan, misalnya: usia, jenis kelamin, agama, dan sebagainya (Morrisan 2008:181). Segmentasi geografis membagi-bagi khalayak audien berdasarkan jangkauan geografis (Morrisan 2008:187). Segmentasi psikografis adalah segmentasi berdasarkan gaya hidup dan kepribadian manusia (Morrisan 2008:189).

\section{- Penentuan Lingkungan Implementasi}


Untuk melakukan tahap praproduksi, produksi, dan pascaproduksi diperlukan penentuan lingkungan implementasi untuk menentukan pada lingkungan seperti apa sajakah proses-proses pada ketiga tahapan tersebut akan dijalankan. Lingkungan implementasi dibagi menjadi dua, yakni perangkat lunak dan perangkat keras.

\section{- Penulisan Naskah / Script (Scriptwriting)}

Penulisan naskah / script dimulai dari mengumpulkan ide-ide yang bersesuaian dengan topik dan target audience yang telah ditentukan sebelumnya. Ide berbentuk rencana adegan atau dialog yang dapat menggambarkan permasalahan pada topik serta solusi untuk menyelesaikan permasalahan dengan berlandaskan ajaran Islam. Selain itu ide juga bisa berupa adegan atau dialog yang disisipi unsur humor. Tujuan penyisipan unsur humor supaya cerita yang disampaikan tidak terlalu serius (masalah disampaikan secara ringan) sehingga sesuai dengan tujuan dibuatnya konten Kamus Ustadz yaitu menarik dan bermanfaat.

Setelah ide-ide dikumpulkan lalu ide-ide tersebut dituliskan dalam bentuk rancangan adegan dan dialog yang disebut dengan script. Script merupakan hasil kerja tertulis yang menjadi bahan pembuatan film (Effendy 2014:133). Berdasarkan pernyataan tersebut, film yang dimaksud adalah video konten Kamus Ustadz.

\section{- Pembuatan storyline}

Storyline adalah suatu panduan kerja dalam proses pembuatan sebuah informasi yang berisi konsep naskah dari informasi yang akan dikerjakan, sehingga penerapan informasi menjadi suatu perancangan dan implementasi mempunyai panduan yang jelas (Nurhasanah dan Destyany 2011:5). Storyline dijadikan sebagai panduan dalam melaksanakan tahap Produksi dan Pascaproduksi supaya lebih terarah karena mempunyai panduan / pedoman yang jelas dalam pelaksanaannya.

\section{Produksi}

Hendratman (2017:716) menyatakan bahwa produksi adalah tahap pengambilan data yang dibutuhkan sesuai script dan storyboard. Output dari tahap produksi adalah kumpulan footages yang berasal dari proses shooting dan pengumpulan stock footages. Footage merupakan unit pengukuran yang digunakan untuk film, footage berarti juga stok gambar yang pernah direkam (Effendy 2014:114). Footages yang dihasilkan dari tahap produksi berupa gambar, video dan audio mentah yang perlu diolah lebih lanjut pada bagian editing di tahap Pascaproduksi. Rangkaian proses pada tahap produksi adalah sebagai berikut:

\section{- $\quad$ Shooting Scripts / shooting}

Shooting Scripts / shooting adalah pekerjaan akhir sebuah naskah film, membuat detail gambar satu per satu dan memberi nomor untuk urutannya (Effendy 2014:135). Tiap gambar (footages) yang diambil adalah footages dengan resolusi HD / High Definition (1280 pixels $\times 720$ pixels). Selain itu, tiap footages juga diatur supaya frame rate-nya menggunakan 50 FPS (frames per second). FPS yaitu ukuran banyaknya gambar / frame yang tampil dalam satu detik dalam 
sebuah video (Hendratman 2017:724). Dapat diartikan bahwa shooting merupakan proses pengambilan footages (gambar atau video) yang pengambilannya didasari dari naskah / rancangan berupa storyline. Footages yang dihasilkan perlu diolah lebih lanjut pada tahap Pascaproduksi.

\section{- $\quad$ Stock Footages}

Stock footages dibutuhkan untuk melengkapi kebutuhan footages yang tidak dihasilkan di proses shooting. Effendy (2014:139) menyatakan bahwa Stock footages adalah materi siap pakai: mulai dari newsreel, dokumenter, dan fitur film, yang dipandang berguna untuk film. Stock footages dapat berupa gambar, video (video hasil shooting / video jadi pada konten Kamus Ustadz yang lain, video animasi, dan video motion graphics) maupun audio (background music dan sound effects) yang dapat merepresentasikan cerita berdasarkan pada storyline.

Sumber stock footages dapat diperoleh dari hasil karya sendiri / perusahaan ataupun hasil karya orang lain. Gambar yang dipakai adalah gambar vektor dan gambar bitmap. Gambar vektor adalah dasar pada elemen lukisan atau objek seperti garis, lingkaran, segi empat, dan berbagai gambar lainnya yang dilukis dalam bentuk geometrik (formula matematik) untuk menerangkan ukuran, kedudukan dan bentuk gambar tersebut (Munir 2012:293). Gambar bitmap merupakan gambar yang tersimpan sebagai rangkaian pixel (titik-titik) yang memenuhi bidang titik-titik di layar komputer (Munir 2012:285).

Audio didefinisikan sebagai macam-macam bunyi dalam bentuk digital seperti suara, musik, narasi dan sebagainya yang bisa didengar untuk keperluan suara latar, penyampaian pesan duka, sedih, semangat dan macam-macam disesuaikan dengan situasi dan kondisi (Munir 2012:22). Pemilihan audio pada stock footages meliputi pemilihan background music (musik latar belakang) dan sound effect (efek suara). Background music yaitu musik yang berfungsi untuk melatarbelakangi atau menggiring materi yang dibawakan (Romli 2017:42). Musik latar belakang (background music) diperdengarkan pada waktu teks diucapkan (Priatna 2018:106). Sound effect (sering disingkat FX) yaitu suara tiruan atau sebenarnya yang menampilkan daya imajinasi dan penafsiran pengalaman tentang situasi yang sedang ditampilkan (Romli 2017:43).

Video yang digunakan sebagai stock footages adalah video hasil shooting pada konten Kamus Ustadz yang lain, video animasi dan video motion graphics. Video hasil shooting pada konten Kamus Ustadz yang lain dapat digunakan apabila video tersebut dapat menggambarkan cerita pada konten Kamus Ustadz yang sedang dibuat. Video animasi atau animasi merupakan teknik untuk membuat sebuah karya audio visual agar menghasilkan urutan gambar yang membentuk satu adegan (Herliyani 2014:7). Video animasi yang digunakan yaitu video animasi hasil karya orang lain yang dapat digunakan secara bebas (bebas royalti). Video motion graphics adalah kombinasi grafis-teks-animasi, gambar/foto/footage indah dan kemajuan efek visual digital dan animasi dalam film menjadi daya tarik tersendiri (Mahardika dan Fathoni 2013:1184). Betancourt (dalam Satria 2012:6) mengemukakan bahwa motion graphics adalah grafik yang menggunakan footage dari video atau teknologi animasi untuk menciptakan ilusi dari motion atau gerakan dan biasanya dikombinasikan dengan audio untuk digunakan dalam projek multimedia. Video motion graphics yang digunakan 
adalah hasil dari karya sendiri.

\section{Pascaproduksi}

Tahap pascaproduksi adalah tahap mengolah data-data yang diambil di tahap produksi, sehingga bisa menjadi bahan jadi / final yang siap untuk diedarkan (Hendratman 2017:717). Data-data yang dimaksud adalah kumpulan footages yang merupakan output dari tahap produksi. Hasil akhir dari tahap pascaproduksi adalah video yang telah berhasil dipublikasikan di ROOV. Rangkaian proses pada tahap pascaproduksi adalah sebagai berikut:

\section{- $\quad$ Editing}

Proses editing merupakan tahap pengolahan lebih lanjut pada footages. Sweetow (2011:287) mengemukakan bahwa editing adalah menggabungkan video - video dalam suatu metode yang terorganisir, termasuk penambahan narasi voice-over, musik, teks, grafis, dan efek khusus. Tahap editing dibagi menjadi 2 yaitu offline editing dan online editing yang keduanya dibagi-bagi lagi menjadi poinpoin seperti berikut :

a. Offline editing merupakan tahap penyuntingan kasar yang intinya adalah menyambung cuplikan gambar terbaik dari setiap adegan dan menyambungkan menjadi satu kesatuan adegan yang berkesesinambungan (Mabruri 2018:335). Offline editing dibagi menjadi beberapa bagian, yaitu :

- Menata dan menyeleksi kumpulan footages

Kumpulan footages ditata berdasarkan jenisnya yakni video, audio, dan gambar. Tiap jenis footages diseleksi lalu disimpan di dalam 1 folder yang sejenis. Footages yang sekiranya tidak sesuai maka tidak masuk seleksi.

\section{- Membuat sequence}

Sequence adalah tempat dimana anda memasukkan audio / video klip mentah dan membuatnya menjadi video jadi (Silber 2011:99). Diperlukan pengaturan pada sequence supaya video yang akan dihasilkan nantinya dapat sesuai dengan yang dikehendaki.

\section{- Impor footages}

Impor footages dilakukan supaya kumpulan footages dapat diolah lebih lanjut dalam editing. Setelah kumpulan footages diimpor, footages baru dapat diolah lebih lanjut pada sequence yang sebelumnya telah dibuat.

\section{- Rough cut}

Effendy (2014:132) mengemukakan bahwa rough cut adalah penggabungan pertama kali dari berbagai adegan film menurut suatu cerita yang komprehensif. Pada rough cut dilakukan penyusunan footages video dari proses shooting berdasarkan cerita pada storyline. Dilakukan juga teknik cut yaitu transisi instan dari suatu gambar ke gambar lainnya (Effendy 2014:107). Teknik cut pada rough cut masih memotong footages secara kasar saja karena tujuan dari rough cut sendiri adalah menyusun footages supaya sesuai dengan cerita. 
b. Online editing merupakan proses akhir editing untuk menyempurnakan, mempercantik, dan memperindah gambar setelah proses offline (Mabruri 2018:335). Online editing dibagi menjadi beberapa bagian, yaitu :

\section{- $\quad$ Fine cut}

Tomaric (2011:415) mengemukakan bahwa fine cut dapat diartikan sebagai quality control secara teknis terhadap proses rough cut. Hal teknis yang dimaksud misalnya adalah memastikan apakah kontinuitas tiap shot sudah benar, penetapan tiap shot apakah sudah diatur ke waktu yang tepat, dan memastikan apakah dialog pada tiap scene sudah benar atau belum. Fine cut melakukan cut (memotong) lebih detail pada video-video yang ada pada sequence guna mempersingkat durasi video.

- Penambahan footages pendukung

Footages pendukung adalah stock footages berupa gambar dan videoyang sebelumnya sudah diimpor pada tahap impor footages atau dibuat langsung saat proses editing berlangsung.

- Penambahan background music \& sound effects

Background music \& sound effects merupakan footages audio yang sebelumnya sudah diimpor pada tahap impor footages. Pada tahap ini background music \& sound effects disusun sesuai dengan cerita pada video.

- Penambahan visual effects

Visual effects merupakan efek-efek tertentu pada perangkat lunak editing yang dapat memanipulasi tampilan video, dapat berupa video effects dan juga dapat berupa transisi video yang diunduh dari internet di Youtube (www.youtube.com). Transisi adalah proses perpindahan gambar antara shot satu dengan shot yang lain (Wulandari dan Pratiwi 2016:6).

- Penambahan subtitle

Subtitle adalah kata-kata yang muncul di bagian bawah sebuah gambar tepat pada saat sebuah dialog sedang diucapkan (Effendy 2014:139). Subtitle mengantisipasi apabila dialog antar tokoh tidak terdengar.

\section{- Render}

Render merupakan proses kompresi hasil editing (project video) menjadi video digital. Kompresi merupakan suatu metode untuk menekan data menjadi ukuran yang lebih kecil untuk disimpan dalam komputer, disc, dan untuk dikirim melalui internet (Sweetow 2011:286). Project video hasil dari proses editing akan dikompresi menjadi ekstensi .mp4.

- Revisi

Menurut $\mathrm{KBBI}$, revisi adalah peninjauan (pemeriksaan) kembali untuk perbaikan. Setelah video di-render maka video akan ditinjau ulang oleh klien untuk ditentukan apakah video sudah layak dipublikasikan atau belum. Apabila klien merasa diperlukan adanya perbaikan maka prosedur pada pascaproduksi akan kembali ke proses editing dan render kembali. Video akan diperbaiki hingga video 
menjadi sesuai dengan yang diinginkan klien.

- Publikasi

Publikasi adalah menyajikan konten video kepada khalayak umum melalui aplikasi ROOV. Publikasi dilakukan apabila konten video sudah sesuai dengan permintaan klien. Konten video akan dipublikasikan ke ROOV menggunakan CMS (Content Management System) milik ROOV.

\section{HASIL DAN PEMBAHASAN}

Pada bab ini dibahas mengenai implementasi dari metode penelitian yang digunakan dalam memproduksi konten video Kamus Ustadz untuk aplikasi ROOV di PT MNC Networks. Video yang dibahas adalah video berjudul Kamus Ustadz Spesial Ramadan.

\section{Kamus Ustadz Spesial Ramadan}

Dalam rangka menyambut bulan Ramadan, pembuatan video konten Kamus Ustadz dengan judul Kamus Ustadz Spesial Ramadhan dijadikan sebagai pengingat kepada pengguna ROOV bahwa Kamus Ustadz selama bulan Ramadan akan dipublikasikan setiap hari (sebelumnya publikasi dilakukan tiap seminggu sekali). Videonya berisikan cuplikan adegan - adegan para aktor yang ada di Kamus Ustadz dan sambutan pendek dari Ustadz Soleh Sofyan selaku salah satu aktor yang berperan di konten Kamus Ustadz.

Selain itu, video ini juga berisi informasi bahwa Kamus Ustadz memiliki prinsip - prinsip yang harus ada pada tiap kontennya yaitu inspiratif, edukasi, dan menghibur.

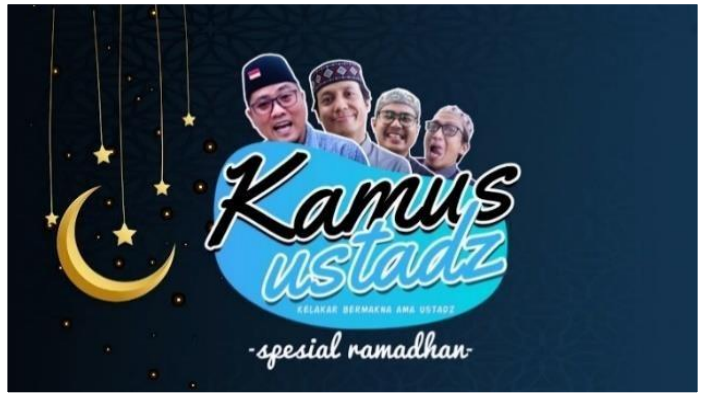

Gambar 2 Cover video Kamus Ustadz Spesial Ramadhan

\subsubsection{Praproduksi}

- Pencarian Referensi

Bulan Ramadan dipilih sebagai topik karena masyarakat Indonesia mayoritasnya beragama Islam yang tentunya melaksanakan kegiatan keagamaan berpuasa pada bulan Ramadan tiap tahunnya.

- Penentuan Target Audience

Penentuan target audience pada video Kamus Ustadz Spesial Ramadhan ditentukan berdasarkan 3 segmen, yaitu:

- Segmentasi demografis: laki-laki dan perempuan dengan usia 20 - 45 tahun. 
- $\quad$ Segmentasi geografis: penduduk di seluruh daerah Indonesia yang melaksanakan aktivitas keagamaan bulan Ramadan.

- Segmentasi psikografis: Orang yang melaksanakan atau tertarik dengan konten bernuansa bulan Ramadan.

- Penentuan Lingkungan Implementasi

Dalam memproduksi konten video Kamus Ustadz Spesial Ramadhan menggunakan perangkat lunak dan perangkat keras, penggunaan lebih rincinya dijelaskan dalam Tabel 1 dan Tabel 2 berikut.

Tabel 1 Perangkat lunak yang digunakan untuk video Kamus Ustadz Spesial Ramadan

Nama Perangkat Lunak Kegunaan

Sistem operasi untuk menjalankan perangkat lunak editing (Adobe Premiere Pro CC 2019, Adobe Photoshop CC 2019, Adobe After Effects CC 2019, Adobe Media Encoder CC 2019).

Memotong \& menggabungkan

Adobe Premiere Pro CC 2019 kumpulan footages hingga sesuai dengan cerita. Memberi video effects pada footages tertentu.

Adobe After Effects CC 2019

Membuat motion graphic Reminder Ramadan.

Adobe Photoshop CC 2019

Editing gambar bitmap untuk dijadikan footages gambar.

Render tiap sequence dari Adobe Premiere Pro CC 2019 dan tiap Adobe Media Encoder CC 2019 composition dari Adobe After Effects CC 2019 lalu mengkompresi keduanya ke dalam bentuk .mp4.

Menuliskan script yang isinya hasil dari diskusi pihak digital content ROOV dan Microsoft Word para aktor Kamus Ustadz dan menyimpannya dalam dokumen berekstensi .docx. 
Microsoft Excel
Membuat storyline yang sumber isinya dari script dan menyimpannya dalam dokumen berekstensi .xlsx.

Tabel 2 Perangkat keras yang digunakan untuk video Kamus Ustadz Spesial Ramadhan

Nama Perangkat Keras

Laptop Asus K401-LB
Menjalankan semua perangkat lunak yang digunakan untuk melakukan editing video Kamus Ustadz Spesial Ramadhan
Kamera Canon EOS 80D dan microphone eksternal RODE
Melakukan proses shooting yaitu pengambilan footages video.

- Penulisan naskah / script (Scriptwriting)

Ide yang tersusun berupa konsep yang dimulai dari menampilkan keunggulan Kamus Ustadz terlebih dahulu kemudian menginformasikan mengenai penggunaan topik bulan Ramadan dan waktu publikasinya. Realisasinya adalah dengan menampilkan beberapa cuplikan adegan Kamus Ustadz yang dianggap menarik sembari menginformasikan prinsip - prinsip yang selalu ada di tiap konten Kamus Ustadz yakni inspiratif, edukasi, dan menghibur. Setelah itu diakhiri dengan penyajian informasi bahwa Kamus Ustadz akan memproduksi konten dengan topik bulan Ramadan dan mempublikasikannya setiap hari.

\section{- Pembuatan Storyline}

Pembuatan storyline bersumber dari script untuk video Kamus Ustadz Spesial Ramadhan. Storyline dibuat oleh penulis selaku salah satu bagian dari pihak digital content ROOV menggunakan Microsoft Excel sehingga menghasilkan output dalam bentuk dokumen berekstensi .xlsx. Setelah dibuat, dokumen di-print untuk dijadikan sebagai pedoman dalam melakukan shooting pada tahap Produksi.

\subsubsection{Produksi}

\section{- $\quad$ Shooting}

Perangkat keras yang digunakan berupa kamera Canon 80D yang telah dilengkapi microphone eksternal. Sebelum shooting kamera diatur terlebih dahulu supaya dapat menghasilkan footages dengan resolusi 1280 pixels $\times 720$ pixels pada 50 fps. Pada proses shooting dilakukan beberapa kali pengambilan gambar (retake) sebab ada beberapa footage yang dirasa belum sesuai dari segi pengambilan gambar / audio.

\section{- $\quad$ Stock Footages}


Stock footages hasil karya sendiri \& perusahaan berupa footages gambar (Gambar 3) yang dibuat menggunakan Adobe Photoshop CC 2019.

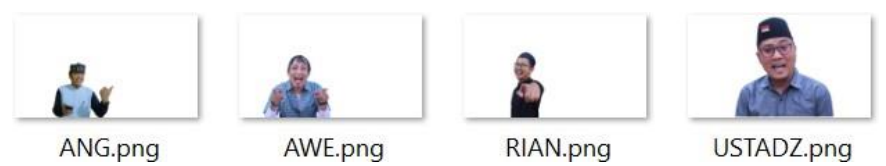

Gambar 3 Stock footages gambar hasil karya sendiri dan perusahaan

Stock footages hasil karya sendiri \& perusahaan berupa footages video berisikan video mentah hasil shooting Kamus Ustadz pada konten Kamus Ustadz yang lain serta video jadi yang telah dibuat sebelumnya menggunakan Adobe Premiere Pro CC 2019 dan Adobe After Effects CC 2019 (Gambar 4 dan Gambar $5)$.

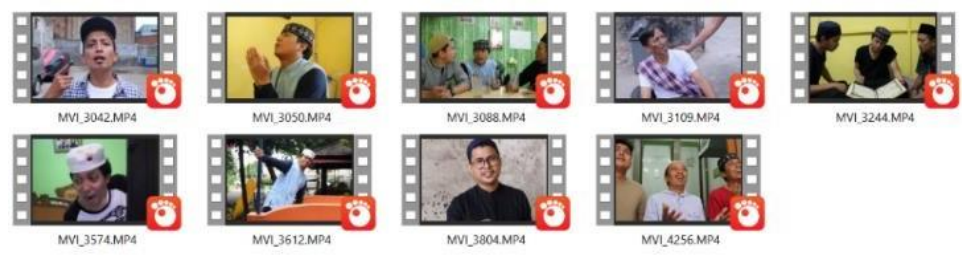

Gambar 4 Video mentah hasil shooting di konten Kamus Ustadz lain

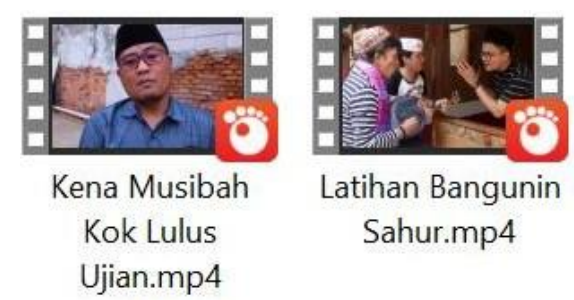

Gambar 5 Video jadi dari konten Kamus Ustadz yang lain

Selain menggunakan video - video tersebut, digunakan juga video jadi yang pernah dibuat menggunakan Adobe After Effects CC 2019 yang sengaja dibuat sebagai pendukung cerita dalam memproduksi video Kamus Ustadz Spesial Ramadhan. Video tersebut bernama Reminder_Ramadhan.mp4 (Gambar 6).

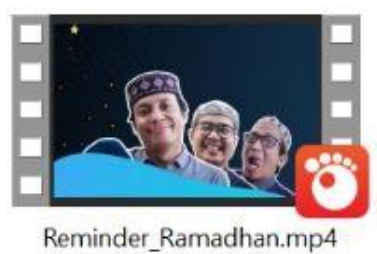

Gambar 6 Video jadi yang dibuat untuk konten Kamus Ustadz Spesial Ramadhan

Stock footages hasil karya orang lain berupa footages gambar, video, dan audio yang diunduh secara gratis dari situs Freepik (www.freepik.com) dan YouTube (www.youtube.com) (Gambar 7). 


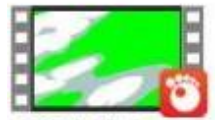

[GS]15 Air Green Screen.mp4

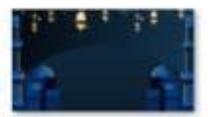

Background_ram adan.jpg

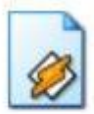

Clink sound.mp3

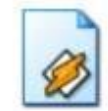

Kevin Macleod

The Builder.mp3

Gambar 7 Stock footages gambar, video, dan audio hasil karya orang lain

\subsubsection{Pascaproduksi}

\section{- $\quad$ Editing}

\section{A. Offline Editing}

a. Menata dan menyeleksi kumpulan footages

Pada footages video hasil shooting, dipilih video yang dianggap paling cocok dalam memvisualisasikan cerita, video tersebut adalah MVI_3977.MP4. Video tersebut dipisahkan dari video-video yang tidak dipakai (Gambar 8) kemudian disimpan di folder video.

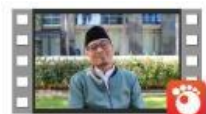

MV_3971.MP4

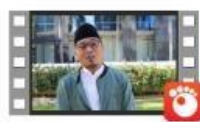

Mn 3976. MP4

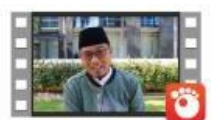

MV1_3972.MP4

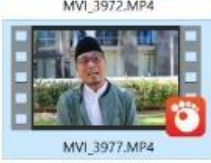

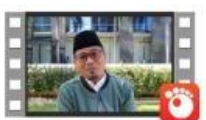

MVI_3973.MP4

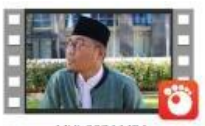

MVI.3974.MP4

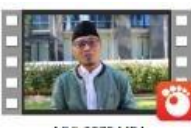

Mv. 3975.MP4

Gambar 8 Footages video hasil shooting yang akan diseleksi

Setelah itu, video hasil shooting dan video stock footages digabung dalam folder yang sama yaitu folder video kemudian diberikan nomor urut pada setiap footages video yang penomorannya didasari atas urutan cerita pada storyline (Gambar 9). 


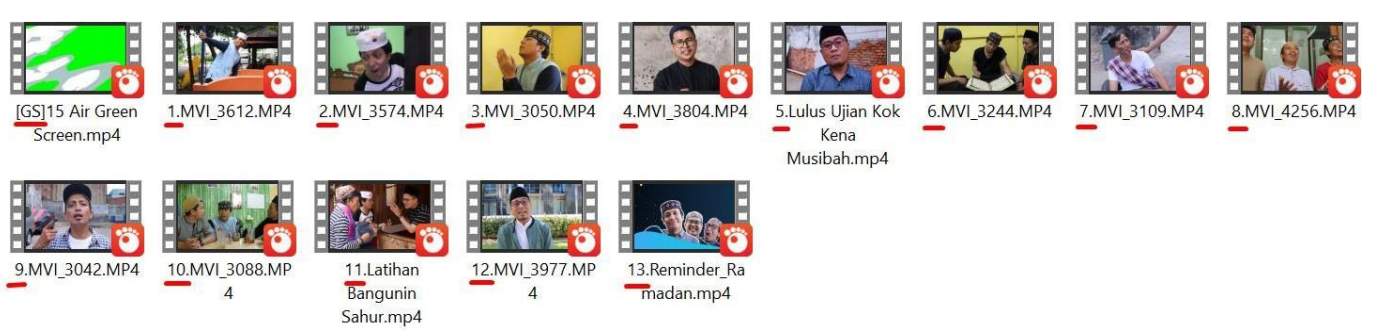

Gambar 9 Footages video stock footages yang sudah ditata

Footages audio berisikan background music dan sound effect. Footages audio disimpan di folder audio. Gambar 10 merupakan footages audio tersebut.

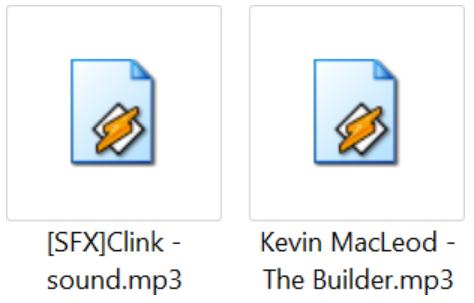

Gambar 10 Footages audio pada video Kamus Ustadz Spesial Ramadhan

Footages gambar berisikan ilustrasi yang dapat mendukung cerita (Gambar 11). Footages gambar disimpan di folder gambar.
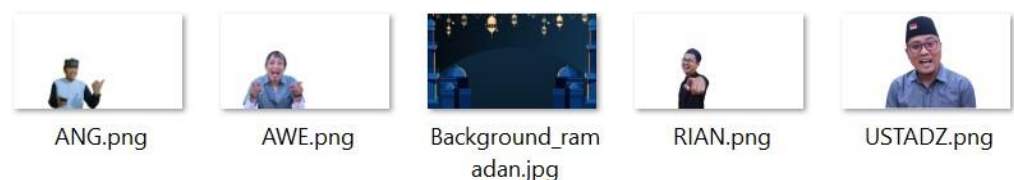

Gambar 11 Footages gambar pada video Kamus Ustadz Spesial Ramadhan

b. Membuat sequence

Dalam membuat sequence digunakan preset yang sudah disediakan Adobe Premiere Pro CC 2019 yakni DSLR 720p50 yang mengatur frame size menjadi 1280 pixels $\times 720$ pixels. Dan frame rate menjadi 50.00 frames/second.

\section{c. Impor footages}

Footages diimpor sesuai folder yang telah dibuat, yakni folder audio, gambar serta video ke dalam Adobe Premiere Pro 2019.

\section{d. Rough cut}

Rough cut pada video Kamus Ustadz Spesial Ramadhan dimulai dari memilih footages video yang dirasa sesuai dengan cerita kemudian menyusunnya pada sequence berdasarkan urutan cerita pada storyline dan terakhir dilakukan teknik cut (memotong) pada footages video tersebut. Setelah video disusun durasi video mencapai 5 menit 13 detik kemudian setelah dilakukan cut pada beberapa video durasinya dapat dipersingkat menjadi 56 detik (Gambar 12). 


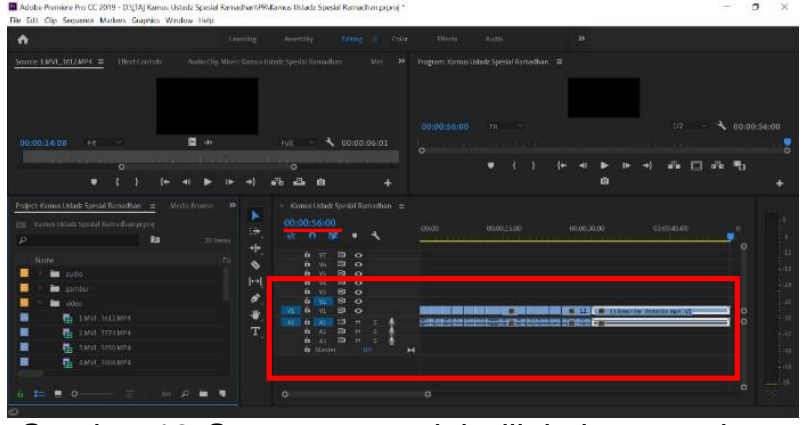

Gambar 12 Sequence setelah dilakukan rough cut

B. Online editing

a. Fine Cut

Fine cut pada video Kamus Ustadz Spesial Ramadhan adalah memanipulasi speed pada footage video terakhir yang bernama 13.Reminder_Ramadhan.mp4 sehingga speed pemutarannya menjadi 150\% (1,5 kali lebih cepat dari video normal).

\section{b. Penambahan Footages Pendukung}

Typography prinsip Kamus Ustadz

Typography ini berisi prinsip - prinsip konten Kamus Ustadz yaitu 'Inspiratif, Edukasi, Menghibur'. Komponen penyusun typography ini yaitu penggabungan berbagai footages gambar di folder gambar dengan greenscreen video di folder video (Gambar 13).

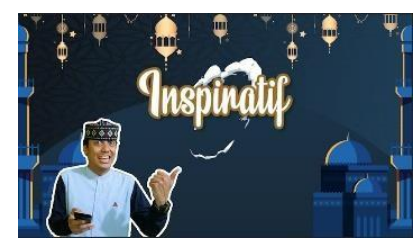

Gambar 13 Typography prinsip Kamus Ustadz

c. Penambahan background music \& sound effects

Background music \& sound effects yang digunakan merupakan stock footages audio yang telah diimpor dan disimpan di folder audio. Background music disusun di sequence pada baris audio ke-3 (A3) sedangkan sound effects disusun pada baris audio ke-2, ke- (A2). Susunannya dapat dilihat pada Gambar 14.

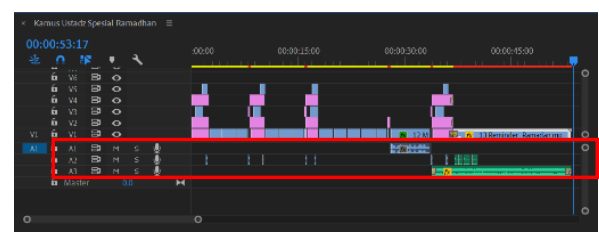

Gambar 14 Susunan audio pada video Tips Nyoblos Ala Kamus Ustadz

d. Penambahan visual effects

- Smooth Slide

Smooth Slide merupakan transisi yang menimpa video sebelumnya oleh video yang akan ditransisikan dengan cara menggesernya dari luar frame ke 
dalam frame di video sembari membuat kedua video tampak blur (kabur) ketika digeser (Gambar 15).

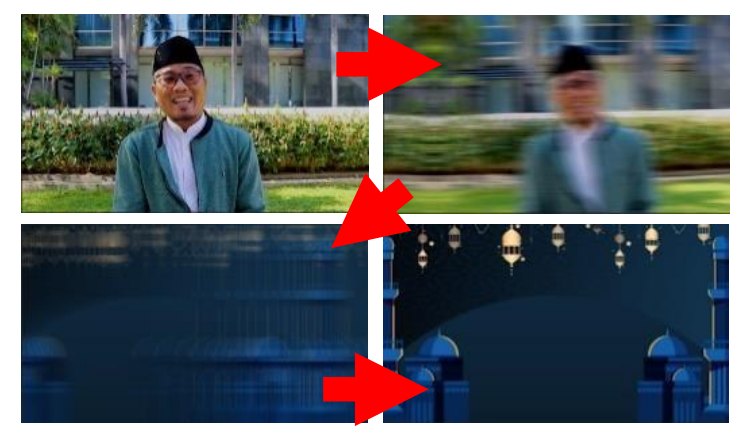

Gambar 15 Contoh video effect Smooth Slide

\section{- Cross Dissolve}

Cross Dissolve merupakan bagian dari transisi dissolve. Pada Cross Dissolve, perpindahan scene sebelumnya ke scene selanjutnya terjadi secara berangsur-angsur dengan scene sebelumnya yang semula jelas lalu memudar secara berangsur-angsur sembari scene selanjutnya dari pudar menuju jelas secara bersamaan (Gambar 16).

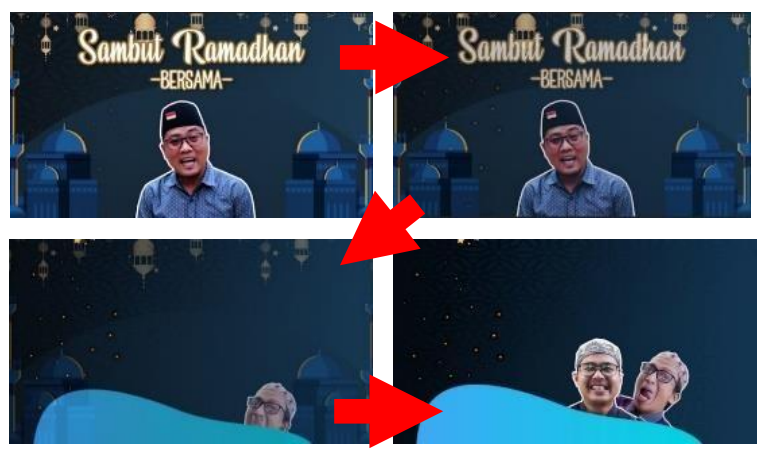

Gambar 16 video effect Cross Dissolve

\section{- Lumetri Color}

Lumetri Color merupakan video effect yang digunakan untuk mengkustomisasi warna pada video ke warna yang diinginkan, seperti pada footage video 12.MVI_3977.MP4. Footage video tersebut pada awalnya memiliki komposisi warna yang sedikit over exposure, kemudian warnanya dikustomisasi sehingga tidak lagi over exposure (Gambar 17).

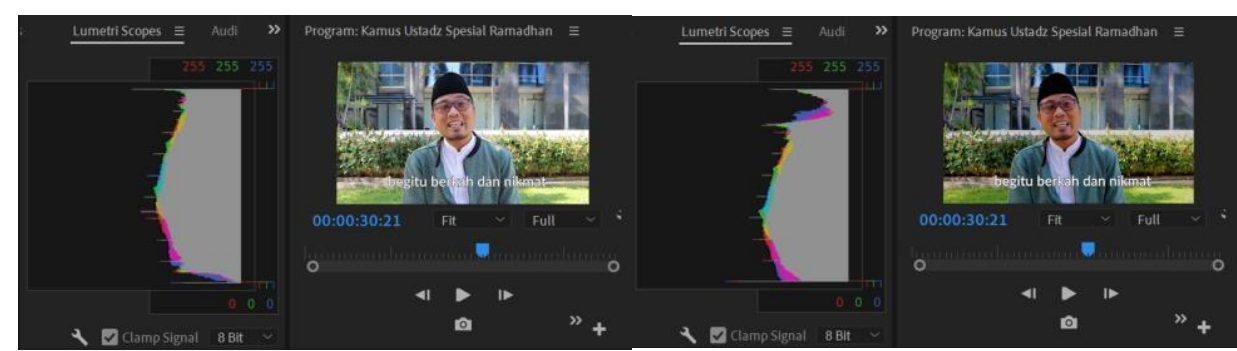

Gambar 17 Cuplikan video sebelum dan sesudah ditambahkan Lumetri Color 


\section{e. Penambahan subtitle}

Subtitle / caption pada video Kamus Ustadz Spesial Ramadhan menggunakan frame size yang sama dengan sequence yakni 1280 pixels $\times 720$ pixels dan timebase yang sama pula yakni $50 \mathrm{fps}$.

Teks pada subtitle menggunakan typeface Lato dengan size 70pt berwarna putih (\#FFFFFF) dengan edge 7pt berwarna abu (\#5E5E5E) tanpa background.

\section{- Render}

Render pada video Kamus Ustadz Spesial Ramadhan yaitu mengkompresi project video-nya (sequence) ke format $\mathrm{H} .264$ supaya menghasilkan video dengan ekstensi .mp4 menggunakan Adobe Media Encoder CC 2019.

- Revisi

Setelah dilakukan peninjauan tersebut, video Kamus Ustadz Spesial Ramadhan dinilai perlu dilakukan perbaikan karena adanya ketidaksesuaian video dengan yang diharapkan oleh klien yang tercantum dalam Tabel 3 berikut.

Tabel 3 Revisi pada video Tips Nyoblos Ala Kamus Ustadz

\begin{tabular}{|c|c|c|c|}
\hline No & Revisi & Sebelum Revisi & Sesudah Revisi \\
\hline 1 & Warna ga & $\begin{array}{lr}\text { Tone } & \text { warna pada } \\
\text { tiap } & \text { footages } \\
\text { banyak } & \text { yang } \\
\text { berbeda. } & \end{array}$ & \begin{tabular}{ll} 
& \multicolumn{3}{l}{ Tone warna pada tiap footages } \\
sudah diatur & ulang \\
menggunakan effect Lumetri \\
Color.
\end{tabular} \\
\hline 2 & $\begin{array}{l}\text { Logo Kamus } \\
\text { Ustadz pada } \\
\text { scene } 10\end{array}$ & $\begin{array}{ll}\text { Munculnya } & \text { tulisan } \\
\text { 'Kamus } & \text { Ustadz' } \\
\text { kurang rapi. } & \end{array}$ & $\begin{array}{l}\text { Munculnya tulisan 'Kamus } \\
\text { Ustadz' pada logo Kamus } \\
\text { Ustadz sudah dirapikan. }\end{array}$ \\
\hline
\end{tabular}

Apabila video sudah diperbaiki dan video sudah dinilai layak oleh klien maka video dapat dilanjutkan ke proses selanjutnya.

- Publikasi

Untuk melakukan proses publikasi, video dipublikasikan ke ROOV menggunakan CMS ROOV. Setelah video dipublikasikan maka video bisa diputar melalui aplikasi ROOV.Video yang sudah berhasil dipublikasikan terlihat seperti Gambar 18 berikut.

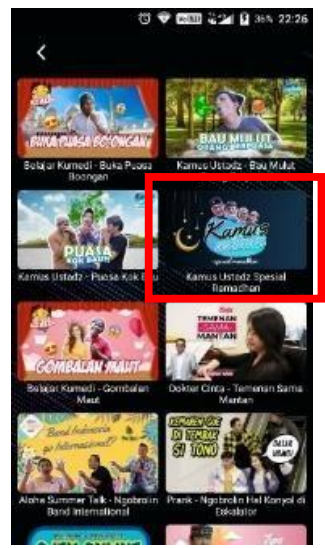

Gambar 18 Video Kamus Ustadz Spesial Ramadhan yang sudah dipublikasikan di ROOV 
Dengan berhasil dipublikasikannya video Kamus Ustadz Spesial Ramadhan ke ROOV maka dapat disimpulkan bahwa video Kamus Ustadz Spesial Ramadhan telah berhasil menjadi video konten religi Islam ROOV yang dipublikasikan secara berkala di ROOV.

\section{SIMPULAN}

Produksi Video Konten Religi Kamus Ustadz untuk Aplikasi ROOV telah selesai diproduksi dan telah digunakan sebagai konten religi yang dipublikasikan di ROOV. Simpulan yang didapat dari produksi video konten Kamus Ustadz ini adalah sebagai berikut :

1 Kedua video hasil dari produksi video konten Kamus Ustadz tersebut berhasil diselesaikan sehingga dapat dijadikan sebagai video konten religi Islam ROOV yang dipublikasikan secara berkala.

2 Video hasil produksi konten Kamus Ustadz dapat menjadi konten yang dapat menarik minat khalayak umum sebab merupakan konten yang menarik dan bermanfaat.

\section{SARAN}

Diperlukan peningkatan kualitas pada setiap produksi konten di ROOV khususnya pada konten Kamus Ustadz terutama pada tahap produksi yakni pada penggunaan perangkat keras yang digunakan untuk proses Shooting (pengambilan gambar dan audio) misalnya dengan penggunaan stabilizer dan penggunaan microphone eksternal yang lebih baik. Sebab apabila kedua hal tersebut lebih ditingkatkan lagi maka gangguan teknis seperti footages yang dihasilkan kurang tajam, tidak stabil (goyang) dan audio yang ber-noise tinggi dapat lebih ditekan lagi yang dapat berdampak pada semakin berkualitasnya konten dari segi teknis sehingga konten dapat berpeluang menarik minat audiensi lebih tinggi untuk menyaksikan konten-konten ROOV melalui aplikasi ROOV.

\section{DAFTAR PUSTAKA}

Effendy H. 2014. Mari Membuat Film. Permatasari L, editor. Jakarta (ID): KPG (Kepustakaan Populer Gramedia).

Hendratman H. 2017. The Magic of Adobe Premiere Pro. Bandung (ID): Informatika.

Hendrawan A, Andono PN, Susanto. 2016. Analisa peningkatan kualitas citra bawah air berbasis koreksi gamma dan histogram equalization [jurnal]. Transformatika. 14(1): 18-22. Semarang (ID): Universitas Semarang.

Herliyani E. 2014. Animasi Dua Dimensi. Yogyakarta (ID): Graha Ilmu. Mabruri AKN. 2018. Produksi Program TV Drama. Jakarta (ID): Gramedia.

Mahardhika S, Fathoni AFCA. 2013. Storyboard dalam pembuatan motion graphic [jurnal]. Humaniora. 4(2): 1183-1189. Jakarta (ID): Universitas 
Bina Nusantara.

MNC. (2019, April 15). Struktur Perusahaan. Diambil dari https://www.mnc.co.id/corporate-structure.

Morrisan MA. 2008. MANAJEMEN MEDIA PENYIARAN:

Strategi

Mengelola Radio \& Televisi. Jakarta (ID): Prenadamendia.

Munir. 2012. MULTIMEDIA Konsep \& Aplikasi dalam Pendidikan. Bandung (ID): CV Alfabeta.

[Nielsen] The Nielsen Company. 2017. The new trend among indonesia's netizens [Internet]. [diunduh 2019 April 15]; Tersedia pada: https://kupdf.net/downloadFile/5a8abfdde2b6f5cd431d6571?preview $=1$.

Nurhasanah Y I, Destyany S. 2011. Implementasi model CMIFED pada multimedia interaktif untuk pembelajaran anak usia TK dan playgroup [jurnal]. Informatika. 2(2): 1-12. Bandung (ID): Institut Teknologi Nasional.

Priatna WB. 2018. PANDUAN KULIAH DAN PRAKTIKUM: Produksi Siaran Radio. Bogor (ID): Idemedia Pustaka Utama.

Romli ASM. 2017. Manajemen Program \& Teknik Produksi Siaran Radio.

Bandung (ID): Nuansa.

Silber J. 2011. Wedding Videography: Start to Finish. Boston (US): Course Technology PTR.

Sweetow S. 2011. Corporate Video Production: Beyond The Board Room (and out of the Bored Room). Burlington (US): Elsevier Inc.

Tomaric JJ. 2011. Filmmaking: Direct Your Movie from Script to Screen Using Proven Hollywood Techniques. Burlington (US): Elsevier Inc.

Wulandari P. 2016. Teknik editing dalam film televisi "Mesin Fotokopi" [jurnal]. Semarang (ID): Universitas Dian Nuswantoro. 